\title{
The Content of the Practical Component in the Training of Future Teachers in the CDIO Format
}

\author{
Elena I. Alenteva* \\ Marina V. Vedenkina \\ Elena V. Ryabova \\ Ludmila N. Davidova \\ Rufina N. Dosaeva \\ Astrakhan State University, Russian Federation; *Corresponding e-mail: elena5080@yandex.ru
}

Doi:10.5901/mjss.2015.v6n6s7p11

\section{Abstract}

\begin{abstract}
The article deals with the essence of the practical component in the training of future teachers. A significant component of the professional training of future teachers in higher education becomes internship in educational institutions. In the process of pedagogical practice, the conditions are most conducive to preparing students to function as a primary school teacher. The project method of teaching students in high school is one of the components of the Worldwide CDIO Initiative (i.e. Conceive Design - Implement - Operate). This method is aimed at providing students with the possibility of independent acquisition of knowledge in solving practical problems. Organization of practices and project activities are equally important mining tools for acquiring competences at all stages of study. In spite of the knowledge acquired in the course of training, competencies are formed only in the actual teaching activities. The CDIO format creates conditions for the formation of students' professional competencies as stated in the federal state educational standards of higher professional education of the bachelor studies on 'Pedagogical education', profile 'Primary education'.
\end{abstract}

Keywords: pedagogical internship, project activities, publication activity, professional competence, future teachers

\section{Introduction}

At the present stage of development of the national high school that involves the development and implementation of innovation, the leadership and entrepreneurship development in training future teaching staff, the implementation of CDIO approach into practice of the Russian educational space, reveals changes in the quality of student training and effectiveness of implementation of educational standards. Astrakhan State University is one of the few higher education institutions of the Russian Federation to join the international project of the Worldwide CDIO Initiative (see www.cdio.org). Despite the fact that the standards are of $\mathrm{CDIO}$ are elaborated for engineering training areas, the initiative is being adapted and applied in the course of vocational training of students of natural sciences and humanities. The implementation of each of the CDIO standards depends on many conditions and resolved with varying degrees of activity and involvement of educational process in high school (Vedenkina \& Dosaeva, 2014). The teachers are faced with the task of strengthening the project-oriented focus and interdisciplinary integration in the process of training future teachers.

Active methods of training students in high school can involve them directly in thinking and decision processes of pedagogical problems (Treshchev \& Sergeeva, 2012). An important tool for perfecting the acquired competences at all stages of student training at the Astrakhan State University is the organization of practices and implementation of project activities. Ley us consider the content of the practical training of students of pedagogical profile of 'Primary education'. 


\section{Organization of Practice and Project Activity of Students of the 'Pedagogical Education. Primary Education' Training Profile}

\subsection{Characteristics of the acquired competencies by students}

In the context of updating the competence-based approach in vocational education, one of the main tasks put forward is the improvement of teacher training. A teacher has a good knowledge of modern educational space, the specifics of the organization of the educational process of different types of educational institutions, successfully adapting to the rapidly changing conditions of society. Therefore, a significant component of the professional training of future teachers in higher education becomes the internship held in educational institutions, contributing to the formation of competencies and becoming professionals.

The challenge of improving educational practices are envisigated by O.A. Abdullina, E.V. Bondarevskaya, T.F. Belousova, L.V. Glazkina, G.M. Kodzhaspirova, T.V. Lavrikova, E.L. Sorochinskaya, E.L. Soboleva, E.D. Rechkina, S.I. Fetisova and others.

The basic principles of the organization of pedagogical internship of student enrolled in 'Pedagogical Education. Primary education' training profile are:

- Compliance of the internship content and its organization with modern requirements towards the teacher;

- Interrelation of internship with the study of theoretical material, the development of creative abilities of students;

- The complex nature of the internship, ensuring the implementation of inter-subject relationship of humanitarian, special, psycho-pedagogical and methodological disciplines, forming meta-subject and special skills;

- Differentiation and individualization of the content and organization of teaching internship, taking into account peculiarities of schools selected for internship, personal characteristics of students, and the level of their preparedness (Alenteva, 2014).

During the pedagogical internship, the conditions are most conducive to prepare students to be a primary school teacher. Firstly, students get acquainted with the system of training and upbringing work of the school, the duties of a teacher, technology of preparation for lessons and extracurricular activities. Secondly, students are being educated of self-control, self-education, self-correcting of pedagogical activity. Thirdly, future teachers master the complex of methods and means of training and education of younger pupils. Fourthly, apart from acquiring a certain set of professional competencies, students also comprehend the structure of pedagogical work as a system.

Competence is a set of interrelated personality traits, knowledge, skills, ways of life, reflecting the requirements specified for the individual. Competence is the ability of the subject to act appropriately, according to the terms of the situation in the direction of obtaining meaningful results of a certain value (Davydova \& Nasikhanova, 2014).

Internship of students of the aforementioned profile is carried out on the third and fourth year. During the internship, the students form the following set of professional competences (PC), as being stated in the federal state educational standards of higher professional education of the Russian Federation for bachelor students of pedagogy ('Pedagogical Education', profile: 'Primary education'):

- PC-1 - able to implement the curricula of basic and elective courses in various educational institutions;

- PC-2 - prepared to apply modern methods and technologies, including informational, and to ensure the quality of the educational process of particular educational level of a particular educational institution;

- PC-3 - able to apply modern methods of diagnosing the achievements of students and pupils, ensure pedagogical support of socialization and professional self-determination of students, preparing them for conscious choice of profession;

- PC-4 - able to take advantage of the educational environment, including informational, to ensure the quality of the educational process;

- 5 PC - ready to be involved in the interaction with parents, colleagues, social partners, interested in ensuring the quality of the educational process;

- PC-6 - able to organize the cooperation of students and pupils;

- PC-7 - ready to ensure protection of life and health of students in the educational process and extracurricular activities;

- PC-8 - in the field of cultural and educational activities: able to develop and implement cultural and educational programs for different categories of the population, including the use of modern information and 
communication technologies;

- PC-9 - able to professionally interact with members of cultural and educational activities;

- PK-10 - able to use domestic and foreign experience in organizing cultural and educational activities;

- PC-11 - able to identify and take advantage of regional cultural educational environment for the organization of cultural and educational activities.

It should be noted that some competence begin to form at the practical classes (PC-1, PC-2, PC-4, PC-8, PC-10, $\mathrm{PC}$-11) with the use of business games, problem solving, modeling lessons, etc., the other - only during internships (PC3, PC-5, PC-6, PK-7, PK-9).

In spite of the knowledge that students acquire in the course of training, competencies are formed only in the actual teaching activities. At the final conference, the students pointed out that the project helped them to overcome the feeling of fear and insecurity in their abilities, while internship has helped to build the necessary competences and reflect on their own teaching. Although competence is the result of learning, it is more likely the result of self-development of the student, and the result of personal growth, self-organization and a coherent synthesis of the activity and personal experience.

Self-education of students is an integral part of the system of continuous education, which gains a particular relevance in modern conditions. It involves self-study of the training courses over a mandatory program or any other issues of student's interest; independent work on various sources of knowledge; the formation of scientific thinking; mastering the methods of scientific research; forms the readiness for constant renewal and the acquisition of new knowledge (Bloom, 1956) and subsequent professional self-education.

Self-educational competence is seen as an integrative personal property, which provides emotional-valuable attitude towards self-development and self-education activities; as the system of knowledge about the planning and implementation of self-educational activity, about the methods of self-upbringing; the subjective-personal experience of efficient development solutions, development and implementation of students' training models for self-educational activity; the readiness for continuous self-development as a professional, self-improvement, self-education in the field of one's future profession. The above competence is based on the experience of self-educational activity.

Self-educational activity of a student is defined as a goal and a way of educational activities of the competent entity, ensuring amateur systematic activities aimed at achieving certain personal and public import educational goals, fulfillment of cognitive interests, cultural and professional needs, qualitative change in personality (i.e. basic and special skills of self-activity, motivation and self-esteem) in self-producing subjectively and objectively new knowledge in a multilevel higher education, which focuses a person on the design of individual achievements and increasing professional competence. Content of the development process of self-educational competence of the student aimed at deepening and systematization of knowledge of self-educational activity as a system, to improve the professional skills (e.g. diagnostic, analytical, forecasting, organizational, reflexive, etc.) in carrying out this activity. Thus, the formation of self-competence is based on the involvement of a student in self-education activity.

The philosophy at the university does not just relate to a flexible response to changes in the environment, but to the ability of university teachers to initiate students to the positive changes in the organization of self-educational activity (Treshchev \& Sergeeva, 2012). When the development of self-educational activity of students involves systemic changes as a factor of organizational interaction. A teacher understands the success of the training as the value of their influence on the formation of self-competence of the student and the ability to organize a student, only then the self-educational activity of students becomes effective. The teachers engaged in development of self-educational activities of students should know the patterns of self-educational activities and the principles of its managed development, patterns of influence on the process of development of individual positions and personal characteristics of students; be able to analyze internal and external signs indicating the need for changes in the organization of the development process, to plan achievable targets of the close and distant development of the self-educational activity of students, to develop criteria for evaluation and correction of the actions.

In the teaching process, one needs to use a variety of methods and forms that facilitate self-educational activity of students. Among them are: problem lectures, discussions, case studies, presentations on one of the proposed topics, projects and research (Chuchalina et al., 2011).

Pedagogical condition of formation of self-educational activity of the student is the inclusion of students in the different types of independent work (e.g. reproducing, reconstructive-variative, heuristic, creative), the development of customized projects of self-educational activity (Zolotareva \& Umarova, 2011), providing a positive trend of motives of the student in the formation of skills of self-educational activity. The inclusion of students in the self-education activity enables to create a mobile and critical thinking of a student in self-educational activity; consistency of knowledge and ways of mastering it; the regulation of self-educational activity; ability to navigate in an increasing flow of scientific and specialized 
information; ability to elaborate an individual creative approach when solving problems of scientific and professional nature, the position of the true subject of the future profession, which generally provides the mastery of self-education competence.

\subsection{The project activities of students}

The project activity as a development source of education sector and a variety of professional-pedagogical activity has formed a sufficiently long period in the history of culture. The project method as a pedagogical idea, technology and form of educational work became widespread in the first third of the XX century. Philosophers note that the project activity of consciousness has the innate nature and it emerged at the early stages of development of society at the level of crafts, the creation myths, children's games.

The project method of teaching students in high school is one of the components of the CDIO initiative (Vybornov et al., 2014). The method is aimed at giving students the possibility of independent acquisition of knowledge in solving practical problems. Project in an educational activity is interpreted as a reasonable, deliberate and planned activities aimed at the development of a certain system of intellectual and practical skills of a student. Technique of organizing the project activity of students includes a set of research, exploration and problem methods, creative in nature, instrumentally aimed at the independent realization of the planned result.

Pedagogical literature offers a great variety of projects' classifications, such as:

- based on the object: natural, technical S\&T), social, 'human';

- based on the subject: group, collective, network;

- based on the intended purpose: industrial, educational, research, acmeological;

- based on the territory covered: international, federal, regional, local;

- based on the field (i.e. field-based): socio-educational, telecommunication;

- based on the subject area: historical, environmental, etc.;

- based on the duration: long term, medium term, short-term;

- based on the degree of novelty: rationalization, invention, heuristic, innovation, and other.

Scholars allocate the following stages of the project: Stage 1 - pre-project (also called preliminary or starting); Stage 2 - the implementation of the project; Stage 3 - the reflexive; and Stage 4 - post-project. Each of these stages, in turn, incorporate certain procedures that make a meaningful, structural, technological, organizational basis for project activities. Let us consider them in more detail.

Pre-project stage. Start of the project is preceded by a step, whose mission is to create preconditions for the success of the design and its psychological-pedagogical, methodical, organizational, material, and technical support. This stage includes the following specific procedures: diagnosis, problematization, goal-setting, conceptualization, formatization of the project (i.e. a way of limiting / rationing the activity of the project participants by defining its borders and scale), its preliminary socialization.

The implementation stage of the project. Each project step inside this phase cannot be arbitrary. It is defined by the logic of creation or transformation of an object of the project and is always correlated with the specific task (i.e. local task), for which one of the parties is responsible in accordance with the previously scheduled program (i.e. plan). At every given moment of the project its participant should be clear about why, in what period of time the action has to be done, what can be the expected results. What role do these results have to play in the general concept of the project.

Reflective stage. Final examination and evaluation of the project make it possible to determine the compliance of the final product obtained with the original plan; if necessary, one needs to make adjustments, decide on the local use of project materials or their replication as to actively put into practice. Reflective stage involves an assessment of not only the product, but also the human result of the project. Reflections shall be made over, first of all, the course of the project and the system of relationships that it has developed. Reflection on the withdrawal from the project is the appeal to the parties themselves and each other in a new way, from the perspective of the acquired experience of joint activities.

Post-project stage follows immediately after the completion of project activities, receiving the representations and evaluation of results. Actions of all stakeholders in the project at this time determine its objective vitality and future fate of the project's 'product'.

Students of the Astrakhan State University presented practice-oriented projects of psycho-pedagogical and sociocultural orientation, such as "Creative Studio 'Art Life", "The eternal light in music, his name - Tchaikovsky!", "Artists of the Great Patriotic War", "Hasten to do good", "Art-miracle", "New Life", exhibition of scientific and creative work "The Face in the window frame of the Universe" and others. 
The materials of the International Seminar on Innovation and reform of engineering education, which was held in Moscow in September 2011, reflect on the newly-defined standards of CDIO, personal competencies, professional skills and attitudes useful in the preparation of future teachers, in particular. The following personal competencies and attitudes are identified:

- Initiative and the desire to take risks;

- Persistence and flexibility;

- Creative thinking;

- Critical thinking;

- Knowledge about one's own personal skills, abilities and attitudes;

- Curiosity and lifelong learning;

- Management of time and resources.

The professional skills and attitudes include the following criteria:

- Professional ethics, honor, responsibility and accountability;

- Professional conduct;

- Planning of one's career;

- Awareness of the pedagogical space.

Analyzing the data of competence and professional skills, it can be noted that the methods of project activities, pedagogical practices and internships on the basis of educational institutions provide an opportunity to prepare the competitive teaching staff of the modern school.

The inclusion of students' project activity in the learning process of the university is relevant and progressive. It contains a huge developing potential, which is especially important in today's schools, aimed at the development of the creative personality of both a teacher and a pupil. Getting into education, the project approach shapes teaching in a form of productive training with independent problem solving (Crawley, 2001; Crawley et al., 2006). From a pedagogical point of view, the project is a creative learning activity, problematic in the form of presentation of the material, practical in its application, smart filling in its content, independent in the nature of obtaining knowledge, undergoing in a constant competition of opinions and suggestions. Thus, the project activity of students of pedagogical specialties is a specific form of organization of educational process in high school; it draws both the students and teachers, being a condition of their interaction and further cooperation.

\section{Publication Activity of Students - Future Teachers}

The problems and peculiarities of modern education in high school include such a thing as publication activity of students. 'Publication activity' refers to the result of the research activities of the author or scientific staff or a collective of authors of the research process (i.e. organization, region, country), embodied in the form of a scientific publication, for example, the journal article, article in a collective collection, proceedings of the conference, monograph, published report on the research work.

The scientific activity of students is one of the forms of organization of extracurricular activities of young people. Any scientific research or part of it must end up in publication. What results do we have in reality? Less than a quarter of the students take part in scientific events held at the university, with the most active among them are senior students (37\%). The main motivations of young people to engage in science, is the desire to express themselves and assert themselves (49\%), the possibility to make use of scientific work in educational activities (34\%) and, finally, the prospect of financial rewards (42\%). The factors of non-participation in the scientific activities of most of the students referred to the lack of interest (65\%), lack of time (47\%) and lack of necessary skills (31\%). After analyzing the data, we can conclude that the motivation for scientific work of students is low, since the activity in the field of science is mainly due to external factors, and passivity are of internal nature, on the contrary.

To increase the motivation of the students to engage in research and project activities as well as to increase the number of student publications, the following measures are required:

- Popularization in the academic world; i.e. explaining the importance of participation in events organized by the university to the students, providing information on the opportunities they can provide;

- The section of scientific activity has to include information on where to start from; how to choose the supervisor for research activities; what are the forms of incentives for research work; publish information about employment opportunities; replicating scientific achievements of students; etc.;

- To hold meetings, gatherings with freshmen, where the teachers with great interest in science will explain the 
importance of participation in research activities, answer the questions, distribute brochures and booklets;

- To conduct classes that promote the formation of scientific writing skills, preparation and execution of projects.

Summarizing the aforesaid, it should be noted that only through activation of cognitive needs and the proper motivation of students their academic engagement and publication activity in particular can be improved. Students are the future teachers at the end of high school, and after the first 5 years in the pedagogical reality in the period of evaluation, it should be mandatory to have research or project activities reflected in publications to provide to the attestation commission.

\section{Expected Results}

The future teacher must learn how to communicate with students and their parents, to navigate easily in the new educational environment and maximize the use of its opportunities in professional activities. This is not an easy task and is highly dependable on personal traits, such as: temperament, communication skills, the degree of training, etc.; students need time to adapt to this environment and feel like a full member of the pedagogical process.

Bachelor studies is the basis for the formation of self-educational activity of students in practical activities. This is because a student mostly uses the didactic means of indirect and long-term management of self-education activity: training projects, search for explanations and evidence of regularities of linkages and relations, the dominance of the independent use of scientific methods of cognition. As a result of their application and assimilation, the student actively acquires self-education competences.

Master studies provide: inclusion of students in research and development of a professional nature, aimed at explaining the phenomena, processes, and the establishment of correlations; theoretical and experimental predication, thereby providing a better level of self-educational activity consisting in deepening and development of key competencies, their application in practice, the participation of a student in solving urgent problems of pedagogy.

Thus, the first stage of higher education (i.e. bachelor) provides a level of self-educational activity sufficient for basic cognitive, professional and self-educational objectives adequate to requirements of the educational standard, which corresponds to the development of key and basic skills. The second stage (i.e. master) is focused on the individual level of self-educational activity in accordance with the personal capacity of a student; on performing activities based on selfacquired knowledge, on the willingness to continuous improvement of the process and product of labor, as well as personal and professional qualities of a graduate, i.e. the formation of special competences. The preference is given to independent learning and collaborative activities with reference to the student's experience, awareness of training.

In summary, it should be noted that the purpose of the implementation of CDIO in Astrakhan State University is to train future teachers, capable of solving real pedagogical problems, successfully interact with all subjects of the pedagogical process, educate and develop the identity of the student as a representative of the younger generation in society.

\section{References}

Alenteva, E.I. (2014), Practical training is the basis of formation of competence of future teachers. Proceedings of the international conference on "Problems of modern education: Trends and Prospects". Astrakhan: Roman V. Sorokin. pp. 288-291.

Bloom, B.S. (1956), Taxonomy of Educational Objectives Book 1: Cognitive Domain. New York: David McKay Company.

Chuchalina, A.I., Petrovskaya, T.S., \& Klukina, E.S. (2011), Worldwide CDIO initiative: Information and methodical edition. Tomsk: Tomsk Polytechnic University.

Crawley, E.F. (2001), The CDIO Syllabus Report - A Statement of Goals for Undergraduate Engineering Education. Cambridge: MIT.

Crawley, E.F., Brodeur, D.R., \& Soderholm, D.H. (2006), The education of future aeronautical Engineers: conceiving, designing, Implementing and operating. Cambridge: MIT.

Davydova, L.N., \& Nasikhanova, A.Z. (2014), Interdisciplinary educational project as a way of the implementation of the global initiative CDIO in training students. Proceedings of the $5^{\text {th }}$ International methodological conference on "Changes in Education in the $21^{\text {st }}$ century: Best International Practices and Russian Experience. How to Form Business Mindset and Innovative Thinking". Astrakhan: Astrakhan State University Publishing House. pp. 88-91.

Treshchev, A.M., \& Sergeeva, O.A. (2012), Designing the educational process of the university in the context of CDIO standards. Modern fundamental and applied researches: International scientific periodical, 2 (5), 92-98.

Treshchev, A.M., \& Sergeeva, O.A. (2012), The worldwide CDIO initiative as context of professional education. [Online] Available: http://edu.sfu-kras.ru/sites/edu.sfu-ras.ru/files/Vsemirnaya_iniciativa_CDIO_kak_kontekst_professionalnogo_obrazovaniya.pdf (September 28, 2015)

Vedenkina, M.V., \& Dosaeva, R.N. (2014), To the question about the project activities of students of pedagogical directions and profiles in the framework of the CDIO. Proceedings of the $5^{\text {th }}$ International methodological conference on "Changes in Education in the 
21st century: Best International Practices and Russian Experience. How to Form Business Mindset and Innovative Thinking". Astrakhan: Astrakhan State University Publishing House. pp. 78-80.

Vybornov, N.A., Levchenko, A.A., Likhter, A.M., \& Smirnov, V.V. (2014), Research practice as a constituent of the worldwide CDIO initiative. Proceedings of the $5^{\text {th }}$ International methodological conference on "Changes in Education in the $21^{\text {st }}$ century: Best International Practices and Russian Experience. How to Form Business Mindset and Innovative Thinking". Astrakhan: Astrakhan State University Publishing House. pp. 17-18.

Zolotareva, N.M., \& Umarova, A.Yu. (2011), Worldwide CDIO initiative: materials for the participants of the International Seminar on Innovation and reform of engineering education. Moscow: MISIS. 